\title{
Oxygen isotopes in minerals of medium-temperature peridotites from Udachnaya kimberlite pipe
}

\author{
Marina A. Gornova1, Alexander G. Polozov ${ }^{2,3}$, Basil A. Beljaev ${ }^{1}$, Sergey I. Kostrovitsky ${ }^{1}$ \\ ${ }^{1}$ Institute of Geochemistry SB RAS, Irkutsk, Russia, \\ ${ }^{2}$ Institute of Geology of Ore Deposits RAS, Moscow, Russia, \\ ${ }^{3}$ Physycs of Geological Processes, University of Oslo, Norway
}

Garnets with depleted oxygen isotopes were found among garnet peridotites from Udachnaya kimberlite pipe (Yakutia, Russia). Oxygen isotope analysis of mineral grains was performed at Far East Geological Institute by the fluorination method using $\mathrm{BrF}_{5}$ and infrared continuous Nd-YAG laser $(\lambda=1.064 \mu \mathrm{m}, \mathrm{CW}$, $100 \mathrm{~W})$, coupled with Finnigan MAT 252 spectrometer. Accuracy was $0.1 \%$ (at 1 S.D. and $\mathrm{n}=5$ ) for NBS-28, NBS-30 standards.

Studied garnet peridotites have a medium temperature calculated range $\left(900-1140{ }^{\circ} \mathrm{C}\right)$, corresponding to a depth interval from 100 to $160 \mathrm{~km}$ of lithospheric mantle (Table1). Garnets of two peridotites (samples 9723, 9730) are plotted in sub-calcic area of harzburgitic paragenesis (G10 type) and the other garnets are plotted in area of lherzolitic paragenesis (G9 type, Grütter et al., 2004).

Table 1. Equilibrium pressure and temperature estimates for Udachnaya xenoliths

\begin{tabular}{|c|c|c|c|}
\hline Sample & Classification & $\begin{array}{c}\mathrm{T} \\
\left({ }^{\circ} \mathrm{C}\right)\end{array}$ & $\begin{array}{c}\mathrm{P} \\
(\mathrm{Kb})\end{array}$ \\
\hline 9720 & $\begin{array}{l}\text { Coarse Med-T lherzolite } \\
\text { ol- } 87 \text {, opx- } 6, \text { cpx-2, Gr- } \\
5\end{array}$ & 922 & 45 \\
\hline $01-183$ & $\begin{array}{l}\text { Coarse Med-T lherzolite } \\
\text { ol-70, opx- } 14 \text {, cpx-2, Gr- } \\
14\end{array}$ & 1000 & 50 \\
\hline 9730 & $\begin{array}{l}\text { Coarse Med-T } \\
\text { harzburgite } \\
\text { ol-82, opx-1, cpx-3, Gr- } \\
14\end{array}$ & 1032 & 52 \\
\hline 9738 & $\begin{array}{l}\text { Coarse Med-T lherzolite } \\
\text { ol-55, opx- } 20-25, \text { cpx- } \\
10, \text { Gr-15-10 }\end{array}$ & 1100 & 57 \\
\hline 9723 & $\begin{array}{l}\text { Deformed Med-T } \\
\text { harzburgite } \\
\text { ol- } 71 \text {, opx- } 21, \text { cpx- } 3 \text {, } \\
\text { Gr- } 5\end{array}$ & 1140 & 59 \\
\hline
\end{tabular}

Brey and Köhler (1990): opx-cpx solvus used for temperature estimates in lherzolite.

O'Neill and Wood (1979): Mg-Fe garnet olivine exchange used for for temperature estimates in harzburgite. Brey and Köhler (1990): Al in orthopyroxene equilibrium used for all pressure estimates.
In 9723 sample the garnet is not zonal by major and rare elements and has L-MREE plateau at $\sim 0.8$ chondrites and HREE rise up to 8 chondrites at $\mathrm{Yb}$ that is similar to "primary magmatic" (fig.1). Clinopyroxene includes two types. The first type forms grains up to $600 \mathrm{mkm}$ with low content of aluminum, chromium, sodium, titanium and $\mathrm{Mg} /(\mathrm{Mg}+\mathrm{Fe}) \sim 0.92-$ 0.93. It demonstrates sharply differentiated REE distribution pattern with high La-Ce content and very low $\sim 0,07$ chondrite at $\mathrm{Yb}$ (Fig. 2). This clinopyroxene, most likely generated from orthopyroxene and inherits low isotope oxygen ration from orthopyroxene (Table 2). A similar composition is common to clinopyroxene $10-20 \mathrm{mkm}$ fringes from orthopyroxene. In addition, we found 100-200 mkm grains of clinopyroxene with higher $\mathrm{Al}, \mathrm{Na}, \mathrm{Cr}$ contents and $\mathrm{Mg \#} \sim 0.914$, similar in composition to clinopyroxenes of high-temperature lherzolites. This sample shows high orthopyroxene abundance (21\%). Thus, this sample of the garnet peridotite is less altered and additional garnet growth did not take place.

In 9730 sample garnet shows a REE distribution pattern similar to the above described (Fig.1). Garnet is zonal: $200 \mathrm{mkm}$ rim demonstrates increase in $\mathrm{CaO}$ content from $\sim 3,5$ to 5,7 wt. $\%$ and reduction of $\mathrm{MgO}$ concentration from $\sim 21$ до $\sim 22$ wt.\%. Clinopyroxene consists of $\sim 200-600 \mathrm{mkm}$ grains with rims that include fine grains of orthopyroxene, olivine and spinel. Among studied peridotites it is marked by the highest concentrations of rare earth elements (Fig. 2). Fine monticellite and apatite grains are found between olivine and clinopyroxene grains. The sample is characterized by low content of modal orthopyroxene $(1 \%)$, depleted in heavy oxygen isotope (Table 2). Clinopyroxene and zonal garnet are most likely due to metasomatic transformation of rocks under the influence of the calcium - rich fluid (melt) possibly associated with the kimberlite magma.

In 9720 sample the garnet is zonal: $\sim 200 \mathrm{mkm}$ rim shows decrease in chromium and calcium concentrations and increase in aluminium, magnesium and titanium contents Garnet is characterized by marked Sm hump at 10 chondrites and $(\mathrm{La} / \mathrm{Yb})_{\mathrm{N}}<1$ (fig. 1). Clinopyroxene forms cluster of grains of irregular shape; larger grains have exsolution lamellae of Opx. Close to clinopyroxene, one can find newly formed fine grains of orthopyroxene, Gr-spinel and zonal olivine. Large olivine grains in these sites are 
also zonal. Clinopyroxene has a differentiated REE distribution: with low concentrations of heavy and high concentrations of light rare earth elements (Fig. 2).
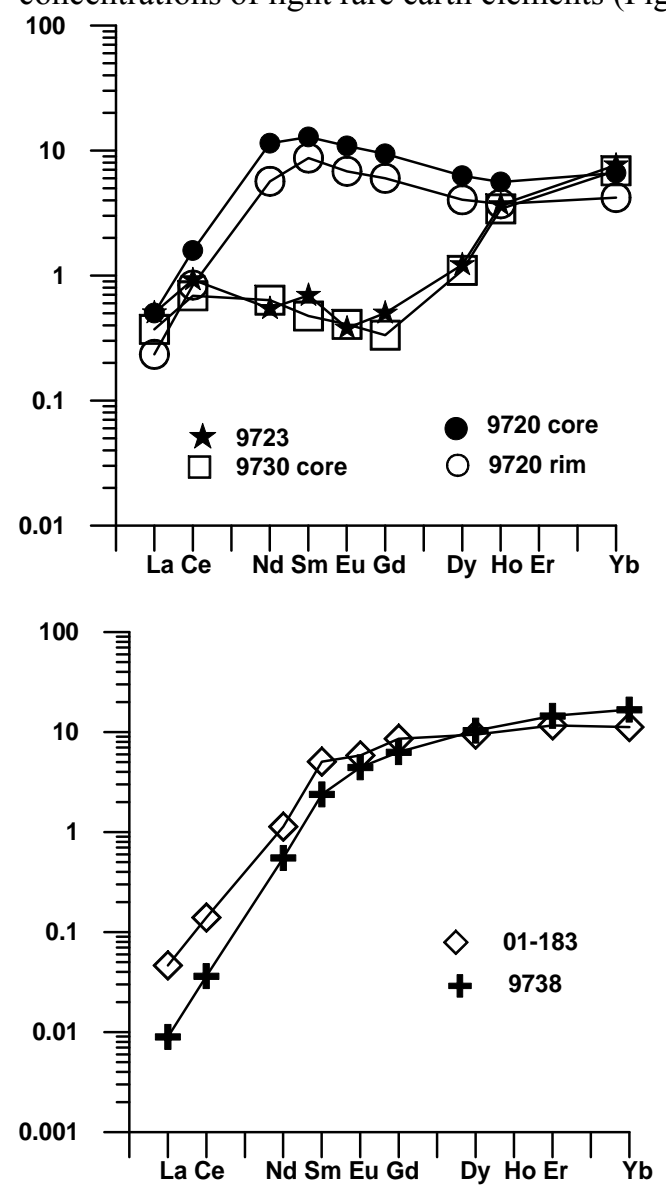

Fig. 1. Chondrite-normalized REE patterns for garnets in Udachnaya xenoliths.

The content of modal orthopyroxene is low $(6 \%)$. This all suggests intensive transformation of the rock as a result of the interaction with the melt.

All these garnets have high $\mathrm{Cr}_{2} \mathrm{O}_{3}(\sim 8-9$ wt.\%) and depleted in oxygen isotope ratio $\left(\delta^{18} \mathrm{O}=4.6 \%\right.$, Table 2) as compared to mantle range $5.37 \pm 0.36 \%$ (Mattey et al., 1994). Oxygen isotopes of olivines (4.9-5.0\%o), clinopyroxenes (5.3-5.6\%o) lie within mantle range. Oxygen isotope fractionation between pyroxenes and olivines correspond to the temperatures calculated from geothermometer ( $\left.\sim 900-1100^{\circ} \mathrm{C}\right)$. Isotope fractionation $\Delta{ }^{18} \mathrm{O}$ garnet-olivine $=-0.3 \%$ and $-0.4 \%$ in these samples indicates isotope disequilibrium for mantle conditions.

Table 2. Laser fluorination oxygen isotope data for Udachnaya xenoliths

\begin{tabular}{|l|c|c|c|c|c|c|}
\hline Sample & \multicolumn{4}{|c|}{$\delta^{18}$ O SMOW $(\%)$} & \multicolumn{1}{|l|}{$\Delta$} & \multicolumn{1}{|l|}{$\Delta$} \\
\hline & Ol & Cpx & Opx & Gr & Cpx-Ol & Gr-Ol \\
\hline 9720 & 4.9 & 5.5 & 5.7 & 4.6 & 0.6 & -0.3 \\
\hline $01-183$ & 5.2 & 5.4 & 6.0 & 5.5 & 0.2 & 0.3 \\
\hline 9730 & 5.0 & 5.6 & 5.2 & 4.6 & 0.6 & -0.4 \\
\hline 9738 & 5.0 & 5.7 & 5.5 & 5.5 & 0.7 & 0.5 \\
\hline 9723 & 4.9 & 5.3 & 5.2 & 4.6 & 0.4 & -0.3 \\
\hline
\end{tabular}
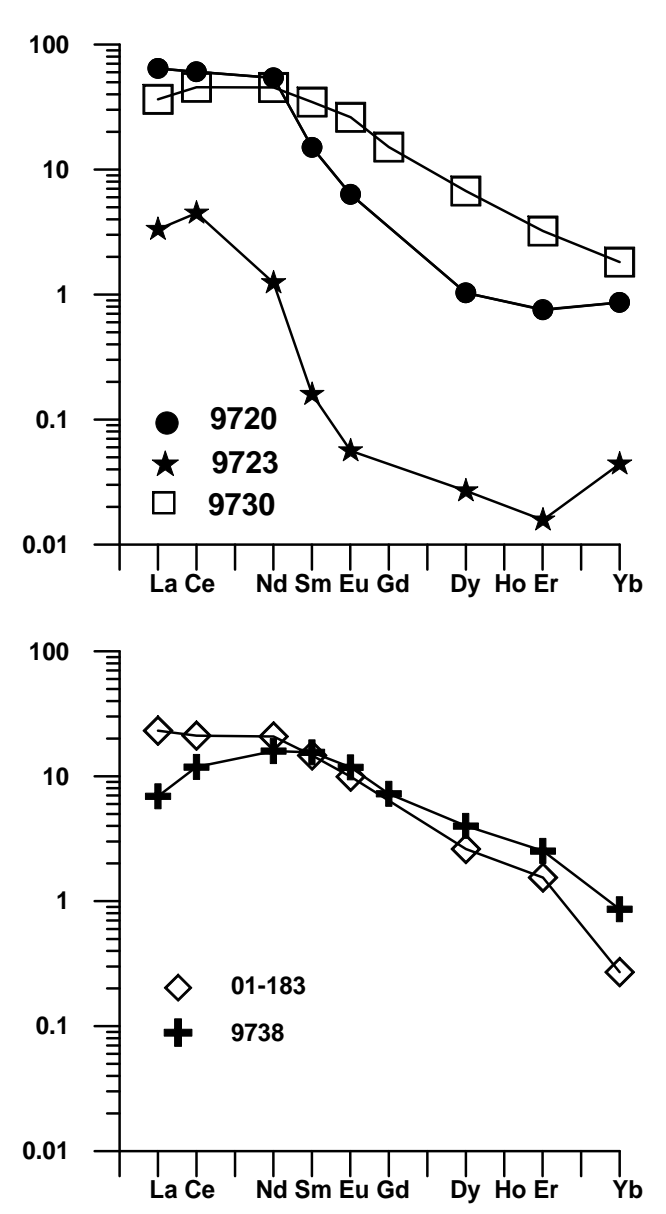

Fig. 2. Chondrite-normalized REE patterns for clinopyroxenes in Udachnaya xenoliths.

In coarse lherzolites (01-183, 9738 samples) garnets have low chromium content (2-4 wt. \%). They are not zonal and have HREE-enriched plateau at 10 chondrites and LREE smoothly decreasing down to 0.01 chondrites at La (Fig. 1). REE patterns are typical of the garnets which are in equilibrium with melt. Such patterns are common to garnets from high-temperature deformed peridotites. In addition, concentrations of other rare elements are similar to those from hightemperature peridotites and are different from highchromium garnets, described above (Fig. 3). The latter have lower concentrations of HFSE, HREE, Y and higher concentrations of Sr, La. Clinopyroxenes form $400-1000 \mathrm{mkm}$ grains, the rims of grains $(50-250 \mathrm{mkm}$ wide) contain fine (to $10-50 \mathrm{mkm}$ ) grains of olivine and pyroxene. The clinopyroxene composition changes from the core towards the rim: concentrations of aluminum, chromium, sodium decrease, while those of calcium and $\mathrm{Mg} /(\mathrm{Mg}+\mathrm{Fe})$ increase. REE distribution patterns in clinopyroxenes show a regular depletion in normalized contents from $\mathrm{Ce}-\mathrm{Nd}$ to $\mathrm{Yb} \sim 0.8-2$ and $\mathrm{La}$ ${ }_{\mathrm{N}}<\mathrm{Ce}_{\mathrm{N}}$ (Fig. 2). Clinopyroxene from these samples has higher $\mathrm{Mg} /(\mathrm{Mg}+\mathrm{Fe})$ and similar LILE concentrations and higher $\mathrm{Hf}, \mathrm{Zr}$, Y concentrations as compared with clinopyroxene from high-temperature peridotites (Fig. 4). By rare-element composition clinopyroxenes are different from clinopyroxenes containing high-chromium garnet (Fig. 4). 

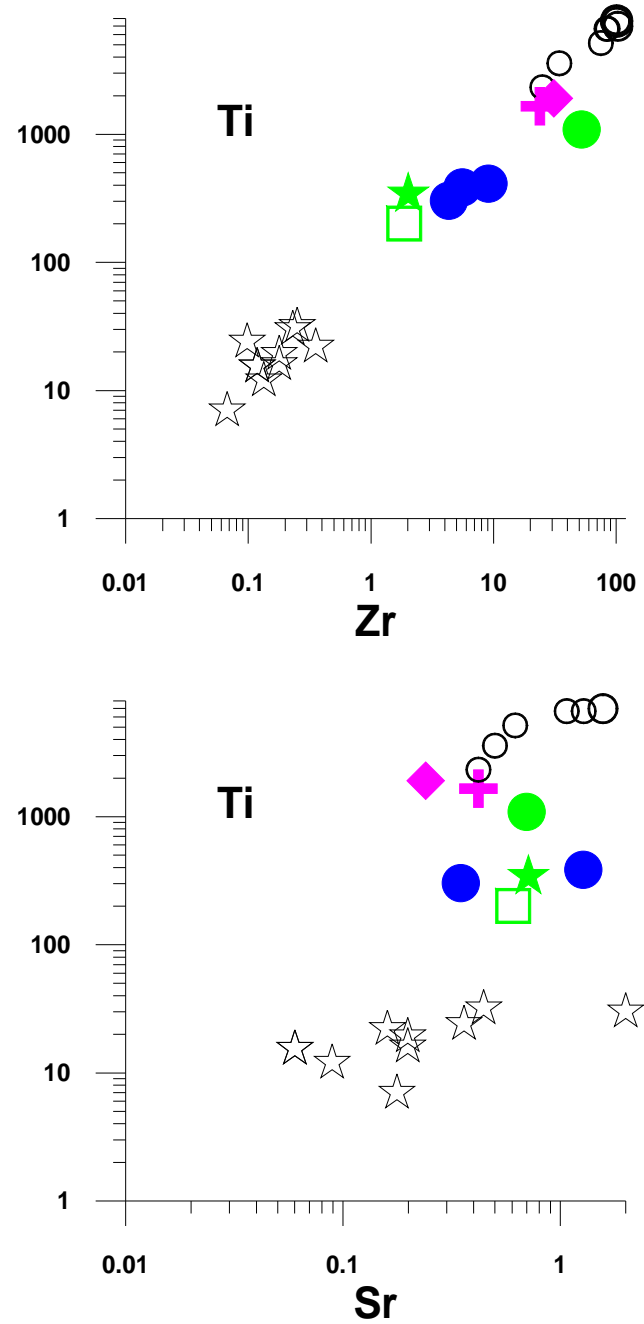

Fig. 3. Ti-Zr and Ti- $\mathrm{Sr}$ for garnets in Udachnaya xenoliths. Peridotites: it -low-T; $\mathrm{O}$ - high-T; metasomatised low-T; $\square$ - 9730; $\star$ - 9723; - 9720 ; $\diamond$ $01-183 ;+-9738$.

This all suggests intensive transformation of the rock as a result of the interaction with the melt.

In these samples $\delta^{18} \mathrm{O}$ values of olivines (5.0-5.2\%o), clinopyroxenes (5.4-5.7\%), orthopyroxenes (5.5-6.0 $\% 0)$ and garnets $(5.5-5.6 \%)$ lie within mantle range (Table 2).

Thus, high-chromium garnets with "abnormal" REE patterns demonstrate isotope disequilibrium with other minerals. Isotope disequilibrium in mantle minerals can be due to influence of subduction-related fluids or melts with low oxygen isotope ratio. So, one could expect the anomalously low $\delta{ }^{18} \mathrm{O}$ values of pyroxenes as compared with garnet and olivine due to different diffusion rates in mantle minerals (Deines and Haggerty, 2000). But the pattern is quite different. It is possible owing to garnet formation by reaction: orthopyroxene + Cr-spinel $\rightarrow$ garnet + olivine. In this case orthopyroxene gives low REE concentrations, while Cr-spinel provides high chromium content and low oxygen isotope values of garnet, as in mantle spinel $\delta$ ${ }^{18} \mathrm{O}=4.37 \pm 0.66 \%$ (Mattey et al., 1994).
Mantle $\delta^{18} \mathrm{O}$ values of low-chromium garnet with "normal" REE distribution are most likely due to
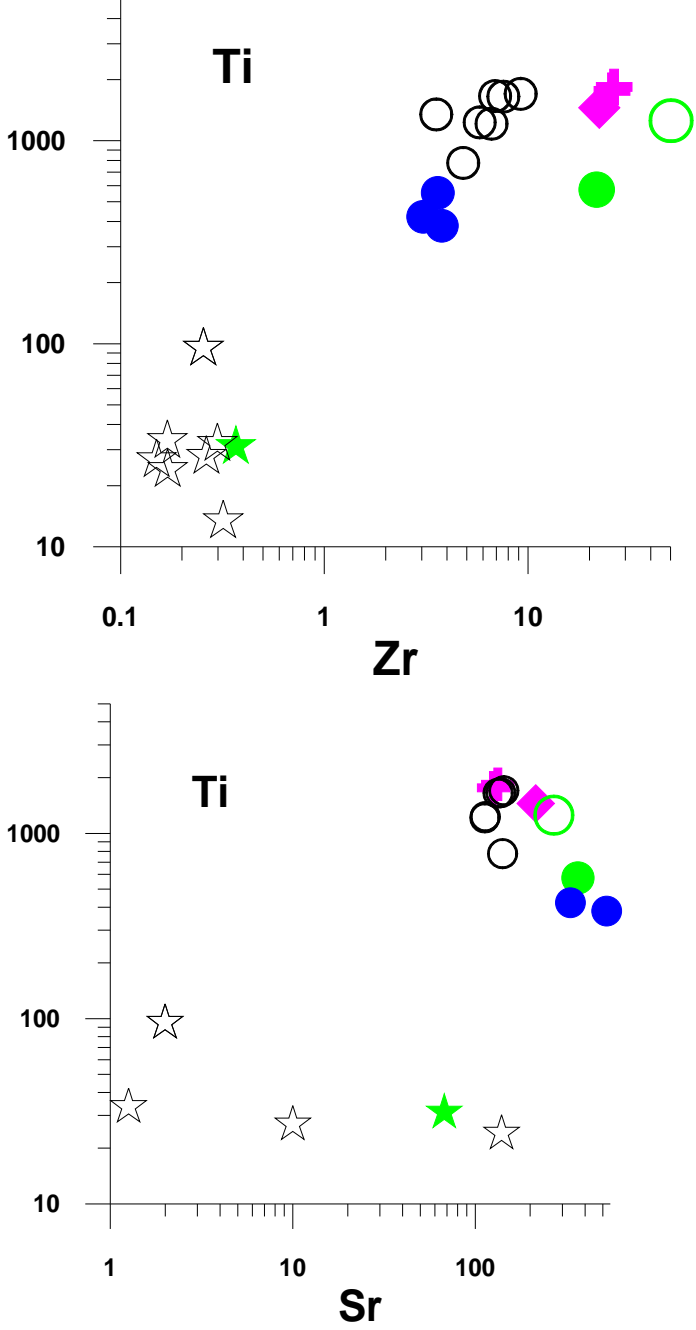

Fig. $4 \mathrm{Ti}-\mathrm{Zr}$ and $\mathrm{Ti}-\mathrm{Sr}$ for garnets in Udachnaya xenoliths.

interaction of protoliths with asthenospheric melts, having mantle oxygen isotopes values, that leads to garnet growth and change in its composition. Such event of garnet growth of pre-existing garnet cores is suggested for high-temperature deformed garnet peridotites (Burgess and Hart, 2004).

\section{References}

Grütter H.S., Gurney, J.J., Menzies, A.H., Winter, F, 2004. An updated classification scheme for mantlederived garnet, for use diamond explorers. Lithos, 77, 841-857.

Deines, P., Haggerty, E., 2000. Small-scale oxygen isotope variations and petrochemistry of ultradeep $(>300$ $\mathrm{km})$ and transition zone xenoliths. Geochim. et Cosmochim. acta., 64, 117-131.

Mattey, D., Lowry, D., Macpherson, C. and Chazot, G., 1994. Oxygen isotope composition of mantle minerals by laser fluorination analysis: homogeneity in peridotites, heterogeneity in eclogites. Min. Mag., 58A, 573-574.

Burgess, S. R., Harte, B., 2004. Tracing lithosphere evolution through the analysis of heterogeneous G9-G10 garnets in Peridotite Xenoliths, II: REE chemistry. J. Petrology, 3, 609-634. 